\title{
Redefinindo o trânsito em julgado a partir da soberania dos veredictos: a coisa julgada parcial no tribunal do júri
}

\author{
Redefining claim preclusion from verdict sovereignty: \\ partial res judicata in jury trials
}

\section{Paulo Gustavo Rodrigues ${ }^{\mathbf{1}}$}

Universidade Federal de Alagoas - Maceió/AL, Brasil rodrigues.paulogustavo@gmail.com

http://lattes.cnpq.br/4136000039136925

https://orcid.org/0000-0001-6670-6557

\begin{abstract}
Resumo: O Tribunal do Júri se apresentou na história como importante instrumento de consolidação de processos democráticos, por se mostrar uma tribuna à qual o povo é convocado para discutir e julgar diretamente fatos ocorridos em sua comunidade. Com a intenção de fortalecer a instituição após um período ditatorial, o constituinte brasileiro resgatou a soberania dos veredictos e ergueu a instituição e suas características ao patamar de cláusula pétrea fundamental. A partir de uma proposta exploratória, de análise qualitativa, o presente trabalho pretende investigar de que forma a soberania dos vereditos impacta no procedimento legal dos crimes dolosos contra a vida a ponto de redefinir o momento inicial de cumprimento da pena, eventualmente justificando hipóteses de execução da pena na primeira, na segunda instância ou após o término definitivo do processo. Discutir-se-á a possibilidade de formação de coisa julgada parcial em relação à culpa do réu ante a natureza subjetivamente complexa da sentença condenatória do procedimento do júri.
\end{abstract}

1 Mestre em Direito Público (UFAL). Especialista em Ciências Criminais (UNIDERP/IPAN), com atualizações em dogmática penal pelo Siracusa International Institute for Criminal Justice and Human Rights e pela Escola Alemã de Ciências Criminais da Universidade de Göettingen. Assessor de Magistrado no Tribunal de Justiça de Pernambuco (TJPE). 
Palavras-chave: Soberania dos veredictos; Tribunal do Júri; Cumprimento da Pena; Coisa Julgada.

ABSTRACT: Jury trials have presented themselves in history as an important instrument for the consolidation of democratic processes, because they are a tribunal for which the people are summoned to discuss and directly judge facts that have occurred in their community. With the intention of strengthening the institution after a dictatorial period, the Brazilian Constituent Assembly rescued the sovereignty of the verdicts, and raised the institution and its characteristics to the level of a fundamental clause. From an exploratory perspective, of qualitative nature, the present work intends to investigate how the sovereignty of the verdicts impacts on the legal procedure of the intentional crimes against the life to the point of redefining the initial moment of compliance to the sentence, possibly justifying hypotheses of execution of the sentence in the first, second degree or after the end of the process. It will be discussed the possibility of forming a partial claim preclusion in relation to the criminal responsibility of the defendant, in face of the subjectively complex nature of the condemnatory sentence of the Jury procedure.

KEYwords: Verdict sovereignty; Trial by a Jury; Enforcement of sentence; Res Judicata.

SUMÁRıO: Introdução. 1. O Tribunal do Júri como direito-garantia fundamental: delimitando o conteúdo normativo da soberania dos veredictos; 2 . O posicionamento constitucional do Tribunal do Júri: um direito-garantia de dúplice aspecto; 2.1. Razões e os reflexos da opção constituinte pela soberania dos veredictos: extraindo seu conteúdo normativo; 3. O sistema recursal como controle posterior e o limite da devolutividade recursal em face das condenações impostas pelo Tribunal do Júri; 4.Redefinindo o trânsito em julgado penal a partir da soberania dos veredictos: a coisa julgada parcial no Tribunal do Júri; 4.1. A coisa julgada parcial a partir da confirmação da condenação em segunda instância; 5. As modificações promovidas pela Lei nº 13.964/2019; Conclusão; Referências 


\section{INTRODUÇÃO}

Após a decisão do Supremo Tribunal Federal acerca do momento inicial de cumprimento da pena, proferida no HC 126.292/SP, observou-se uma proliferação de estudos acadêmicos e decisões judiciais reforçando ou rechaçando o novo paradigma estabelecido.

Tais divergências podem ser tidas como frutos da inconsequente abertura hermenêutica conferida pelo STF à sua decisão, na qual estabeleceu tese deveras ampla, sem preocupação com a fixação de condições ou limites à sua adjudicação judicial. Fauzi Choukr aduz que a decisão "possui repercussões desde as consequências civis em sentido estrito até mesmo aquelas de fruição de direitos da cidadania, como a capacidade eleitoral, sendo que nenhuma dessas dimensões foi sequer tangenciada" ${ }^{2}$. Com isso, os Tribunais se dividiram quanto à execução imediata de penas originalmente estabelecidas em segundo grau (em decorrência de foro por prerrogativa de função), assim como execução de penas restritivas de direito, dentre outras celeumas surgidas.

Mesmo com a modificação do precedente no julgamento definitivo das Ações Diretas de Constitucionalidade $n^{\circ} .43$ e 44, que julgou inconstitucional a execução da pena à revelia do trânsito em julgado da condenação, um dos aspectos da tese continua em discussão ativa, inclusive com adesão aparente de Ministros que votaram pela modificação do precedente original.

Cuida-se do entendimento acerca da possibilidade de execução imediata de penas oriundas de condenações do Tribunal do Júri, ante a norma constitucional da soberania dos veredictos, e é sobre este conteúdo que se debruça o presente artigo.

Em modificação recente, promovida pela chamada Lei Anticrime, o art. 492, I, do Código de Processo Penal passou a prever que as condenações proferidas pelo Tribunal do Júri em que a pena supere 15 (quinze) anos de reclusão já seriam provisoriamente executadas, com recolhimento do réu à prisão.

2 CHOUKR, Fauzi Hassan. A leitura do STF sobre o sistema recursal e o início da execução da pena: a pauperização do comparatismo à brasileira. Revista Brasileira de Direito Processual Penal, Porto Alegre, vol. 4, n. 3, p. 1122. 
Além disso, na data de finalização deste artigo, se encontra em julgamento no STF o Recurso Extraordinário com Repercussão Geral no . 1235340/SC, em que se decide precisamente o objeto deste trabalho, tendo os Ministros Luis Roberto Barroso e Dias Toffoli votado pela constitucionalidade da execução imediata das condenações, independentemente do quantum da pena ${ }^{3}$. Vale observar que o Ministro Dias Toffoli foi um dos que formou a maioria nas Ações de Constitucionalidade que reverteram o entendimento quanto à execução provisória da pena para as condenações em geral, de modo que seu voto pode indicar uma tendência da Corte em decidir a matéria de forma distinta da regra geral.

Das diversas formas de participação popular no complexo universo jurídico, o Tribunal do Júri talvez seja a mais aberta e invasiva delas, permitindo que a sociedade, idealmente representada por seus vários segmentos, ingresse ativamente numa das funções essencialmente estatais, imiscuindo-se no papel de julgador para decidir o destino de um de seus pares.

Pretende-se uma análise exploratória e qualitativa dos aspectos legais e políticos relacionados ao Tribunal do Júri, para se investigar os diversos impactos que a soberania possuiria no microcosmo processual do Tribunal do Júri, e de que forma isso poderia impactar na formação da coisa julgada e no momento inicial de cumprimento de pena.

\section{O TRIBUNAL do JÚRI COMO DiREITO-gaRANTIA FUNDAMENTAL: DELIMITANDO O CONTEÚDO NORMATIVO DA SOBERANIA DOS VEREDICTOS}

Para que se possa defender uma tese que sustente a possibilidade de marcos diferenciados de trânsito em julgado nos procedimentos do júri, em razão da previsão constitucional da soberania dos veredictos, é necessário que se estabeleça qual a extensão e a profundidade de seu conteúdo normativo, para além de sua mera definição gramatical.

Mesmo sem pretensões de um longo escorço histórico, não se pode ignorar o fato de a soberania dos veredictos, no Brasil, ter sido limada

3 Conforme ata de julgamento do dia 04/05/2020, disponível na consulta pública do processo junto ao sítio do STF. 
do ordenamento jurídico durante os períodos constitucionais do Estado Novo e do regime militar, e ter sempre retornado durante os períodos de redemocratização. Esta contextualização é imprescindível, afinal, já dizia Bobbio, os direitos do homem são direitos históricos, "nascidos em certas circunstâncias, caracterizadas por lutas em defesa de novas liberdades contra velhos poderes, e nascidos de modo gradual, não todos de uma vez e nem de uma vez por todas"

Tanto o Tribunal do Júri quanto sua soberania são elementos que sempre estiveram ligados à ideia de consolidação da democracia e de resistência ao Estado, sendo essencial que se construa tal vínculo cíclico de forma detalhada para demonstrar a força histórica por trás da opção constitucional de conferir imutabilidade às decisões populares e, com isso, abstrair toda a sua essência normativa.

Jeffrey Abramson inicia sua obra We, the jury com a afirmação de que "o julgamento pelo júri representa o melhor da democracia e o pior da democracia", e que ele continua a nos atrair e a nos repelir justamente por expor a amplitude dos vícios e virtudes democráticos.

Há aqueles, como Adel El Tasse, que chegam a afirmar que "os críticos do Tribunal do Júri são críticos da própria democracia”, e que, "por detrás dos argumentos retoricamente insinuantes das razões contrárias à atuação popular na administração da justiça, esconde-se o germe do autoritarismo" ". A despeito de seu extremismo, essas são afirmações que guardam certo grau de coerência com o processo histórico de construção e consolidação do júri.

De fato, muitos dos argumentos contrários à instituição do júri sempre esbarram naquilo que se identifica como controverso no próprio processo democrático. Da mesma forma que se costuma expressar indignação pelo fato de se depositar tamanha responsabilidade nas mãos de pessoas leigas, também elas são as responsáveis por eleger os

4 BOBBIO, Norberto. A Era dos Direitos. $8^{\mathrm{a}}$ ed. Rio de Janeiro: Campus, 1992, p. 5.

5 "Trial by a jury is about the best of democracy and about the worst of democracy" (tradução nossa). ABRAMSON, Jeffrey. We, the jury: the jury system and the ideal of democracy. New York: Harvard University Press, 2000, p. 1.

6 TASSE, Adel El. Tribunal do Júri. Curitiba: Juruá, 2006, p. 23.

7 Ibidem, p. 25. 
representantes que nortearão o caminho da nação em seus aspectos mais profundos, inclusive político-criminais.

Da mesma forma que se deseja que os jurados sejam mais qualificados, também se deseja que o sejam aqueles que votam. Como, eventualmente, verificam-se júris malformados com prevalência de determinado gênero, raça ou estrato social, tomando decisões que envolvem classes de pessoas com as quais não possuem suficiente vivência, também no Parlamento há representantes escolhidos por estes estratos que tomam decisões que não necessariamente atendem aos interesses dos demais.

Muitas outras críticas aproximam seus detratores do chamado elitismo democrático, exposto por José Afonso da Silva ${ }^{8}$, que se fundamenta em uma constante desconfiança com o povo, julgando-o intrinsecamente incompetente para o exercício da soberania e defendendo que a democracia somente poderia ser plena após um período de capacitação e instrução, numa visão paternalista e essencialmente antidemocrática.

Não há a pretensão, neste trabalho, de se definir democracia, tarefa que há séculos martiriza os cientistas políticos e que está longe de culminar numa expressão com identidade estática e consensual. Entretanto, não é difícil apontar certos momentos que são historicamente identificados como processos de democratização, e perceber como efetivamente o Tribunal do Júri sempre se relaciona com eles. Necessário, portanto, que se construa esta contextualização para que se possa compreender o ciclo normativo que o correlaciona aos processos democráticos.

A princípio, embora haja registros de julgamentos populares em épocas mais antigas, como na Palestina, Grécia e Roma, estes não guardam relação com o Júri da modernidade, pois, como lembra Fragoso, "são apenas formas de participação do povo nos julgamentos, as quais se explicam pela deficiência do aparelho judiciário, constituindo manifestações primitivas da administração da justiça" ". O júri como hoje se conhece é tido como oriundo da tradição inglesa insculpida na Magna

8 SILVA, José Afonso da. Curso de Direito Constitucional Positivo. 26a ed. São Paulo: Malheiros, 2006.

9 FRAGOSO, Heleno Cláudio. A Questão do Júri. In: Revista Forense. no 193, 1961, p. 20. 
Carta de 1215, previsto com a intenção de se fazer prevalecer os costumes da terra em detrimento da vontade do monarca soberano. Desde o início, portanto, ele se mostrou um instrumento de controle do Estado e proteção do povo, mesmo que, à época, o povo protegido não fosse a grande massa dos governados, mas os barões ingleses.

Com o advento da Revolução Francesa, em 1789, a instituição do júri foi importada ao continente europeu, mantendo seu espírito de fazer prevalecer a vontade do povo em detrimento daquela de juízes vinculados a uma agenda estatal autoritária, construída no ancien régime. Nucci destaca que, naquele momento, o júri se mostrou "a lufada de democracia necessária à Europa"10, razão pela qual se espalhara rapidamente por praticamente todo o continente.

Todavia, a partir da identificação e repúdio a certas vicissitudes do instituto, associadas à criação de garantias e prerrogativas às instituições judiciais e o fortalecimento da democracia, o júri passou a ser superado em diversos países europeus, ou por meio de uma total extirpação ou mediante a substituição pelo sistema de escabinado (em que há um órgão julgador formado conjuntamente por leigos e togados), mantendo-se com força principalmente em países ligados à tradição do common law, além de outros como a Espanha, que o revitalizou nas últimas décadas após sua exclusão durante o período militar ${ }^{11}$.

Faz-se esta breve regressão histórica do surgimento do júri para correlacionar com a realidade brasileira, de modo a demonstrar como a instituição sempre é tida como um instrumento necessário à consolidação de um regime democrático. Como destacou Alexis de Tocqueville, o júri é uma instituição essencialmente política, e deve-se considerá-lo "um modo da soberania do povo; convém rejeitá-lo inteiramente, quando se repele a soberania do povo, ou relacioná-lo com outras leis que estabelecem essa soberania"12.

10 NUCCI, Guilherme de Souza. Júri: Princípios Constitucionais. São Paulo: Ed. Juarez de Oliveira, 1999, p. 33.

11 THAMAN, Stephen C. Spain returns to Trial by Jury. In: Hastings International \& Comparative Law Review. Vol. 21, n²41, 1998. Disponível em: <https://ssrn.com/abstract=2571420>. Acesso em 12.2.2018.

12 TOQUEVILlE, Alexis de. A Democracia na América: leis e costumes. $2^{\mathrm{a}}$ ed. São Paulo: Martins Fontes, 2005, p. 320. 
No Brasil, o júri foi importado ainda no período colonial, como resultado da influência política e jurídica que a Inglaterra tinha em Portugal, passando por diversas transformações de competência e estrutura durante os anos de colônia, Império e República. Criado em 1822 para os crimes de imprensa, foi mantido nas Constituições de 1824, 1891 e $1934^{13}$.

Entretanto, ao se chegar à Constituição de 1937, outorgada pelo Estado Novo de Getúlio Vargas, não se vê nenhuma previsão acerca do Tribunal do Júri, surgindo ele apenas no Decreto-lei no 167/1938, que regulou sua instituição, mas efetivamente lhe excluiu a soberania. $\mathrm{Na}$ prática, criava-se uma aura de julgamento popular, porém com a decisão final a recair sobre o Poder Judiciário, já que havia ampla possibilidade de revisão meritória.

No restabelecimento da democracia, em 1946, o Tribunal do Júri voltou ainda com mais força, no capítulo de direitos e garantias individuais do texto constitucional, em contraposição às Constituições anteriores, que o colocavam no capítulo atinente ao Poder Judiciário. Guilherme de Souza Nucci destaca que o retorno do júri na Constituição de 1946 não teria se dado por questão de utilidade ou confiança na instituição em si, mas por ele representar "um foco de democracia, uma tribuna livre onde as causas são debatidas e apreciadas diretamente pelo povo" ${ }^{14}$, sendo efetivamente uma declaração política de rejeição do autoritarismo de 1937. Fragoso destaca que essa reação do Constituinte de 46, embora explicável sob uma perspectiva política, era fundada em uma concepção romântica do Tribunal do Júri ${ }^{15}$.

Um padrão começa a ser estabelecido, com o júri sempre surgindo como um instrumento de democratização do poder, seja no curso dos processos revolucionários europeus, seja no ordenamento interno

13 A historiografia contida neste tópico do trabalho é obtida em análise dos documentos constitucionais mencionados, além de também constar nas seguintes obras: NUCCI, Guilherme de Souza. Júri: Princípios Constitucionais. São Paulo: Ed. Juarez de Oliveira, 1999, p. 36-40; STRECK, Lênio Luiz. Tribunal do Júri: símbolos e rituais. $3^{\mathrm{a}}$ Ed. Porto Alegre: Livraria do Advogado, 1998, p. 73-74; MARQUES, José Frederico. O júri no direito brasileiro. $2^{\mathrm{a}}$ ed. São Paulo: Saraiva, 1955, p. 55-59.

14 NUCCI, Guilherme de Souza. Op. cit., 1999, p. 41.

15 FRAGOSO, Heleno Cláudio. Op. Cit., p. 22, 
brasileiro. Ele sempre era suprimido ou inutilizado no autoritarismo, mas retornava ou surgia durante processos constituintes democráticos, como uma reação de desconfiança para com o Estado e com o Poder Judiciário construído durante o período que se pretendia superar.

A Constituição de 1967, produzida pelo governo militar, não foi diferente; embora tenha mantido o júri, retirou-lhe a soberania por meio da Emenda Constitucional $n^{0} 1 / 69$, produzida no auge do período de repressão chamado de "anos de chumbo", abrindo margem para que o Poder Judiciário revisasse com amplitude as decisões tomadas pelo povo.

Pelo exercício histórico já realizado, não há como deixar de perceber o quão sintomático foi - durante o regime militar - a supressão da soberania do povo e a transferência da competência revisora plena ao Poder Judiciário.

O fato é que, quando o Brasil enfrenta seu último período de redemocratização, tamanha era a ideologia de resistência política que orientou o Poder Constituinte que o Tribunal do Júri surgiu com ainda mais força, não só se consolidando no capítulo de direitos fundamentais, com sua soberania restabelecida, mas sendo ambos fortalecidos como cláusula pétrea, inexpurgável, portanto, pelo constituinte derivado ou pelo legislador ordinário.

Assim como Nucci observou para o texto constitucional de 1946, não parece que esse retorno tenha algo a ver, necessariamente, com um reconhecimento do Constituinte do sucesso ou da fundamentalidade da instituição do júri, sendo essencialmente uma declaração política de que a consolidação da democracia exige que a voz do povo seja ouvida e levada em consideração, nas suas mais diversas facetas, e que sua participação nos ditames do rumo da nação não mais poderia ser ignorada.

Destaca-se, novamente: há um padrão histórico, uma repetição normativa de o Tribunal do Júri sempre surgir em épocas de revolução ou democratização, como um ato de resistência ou rejeição ao Poder Judiciário construído no período autoritário. Ao final, o júri sempre representou um exemplo da tradição liberal de medo da tirania estatal ${ }^{16}$, e isso tem reflexos indiscutíveis quando se pretende analisar o conteúdo normativo

16 ABRAMSOM, Jeffrey. Op. cit. 
da soberania dos veredictos e seus efeitos processuais, especialmente na democracia brasileira dos dias de hoje.

José Afonso da Silva afirma que a democracia é "um processo de convivência social em que o poder emana do povo, há de ser exercido, direta ou indiretamente, pelo povo e em proveito do povo"17, construindo-se e aprimorando-se a partir de uma dialética com experiências bem e malsucedidas, mas sempre com uma cultura política orientada por valores construídos na base e a partir dela direcionados.

Como dito anteriormente, alguns países europeus que adotaram o Tribunal do Júri foram sistematicamente abandonando-o, ou substituindo -o por um órgão julgador misto (escabinado), à medida que os processos democráticos iam se consolidando e a confiança na legitimidade do Poder Judiciário ia se fortalecendo.

Concordamos com Vasconcelos e Galicia quando afirmam que, embora "a participação cidadã na justiça criminal se mostra compatível com um processo penal democrático”, são necessárias reformas nos procedimentos para melhor adequá-lo às demais garantias constitucionais historicamente construídas na defesa do indivíduo ${ }^{18}$. Diante disso, passemos a analisar de que forma o Júri se posiciona dentro do espectro de garantias fundamentais.

\section{O posicionamento CONSTItUCIONAL do TRIBUNAL Do JÚRI: UM DIREITO-GARANTIA DE DÚPLICE ASPECTO}

Quando do seu posicionamento no texto de 1988, o Tribunal do Júri foi inserido no capítulo de direitos e garantias fundamentais, e, embora não haja consenso acerca da sua natureza materialmente constitucional, é certo que formalmente houve a opção do Constituinte de incluí-lo entre as cláusulas pétreas. Com a intenção de abstrair todo o extrato normativo da soberania dos veredictos, é necessário que se o faça

17 SILVA, José Afonso da. Op. cit., p. 126.

18 VASCONCELOS, Vinícius Gomes de; GALICIA, Caíque Ribeiro. Tribunal do Júri na Justiça Criminal Brasileira: Críticas e Propostas de Reforma para a Restituição de sua Função de Garantia no Processo Penal Democrático. Revista Eletrônica de Direito Processual - REDP. Volume XIII, n. 13, 2014, p. 926. 
através do posicionamento do Tribunal do Júri dentro de uma teoria dos direitos fundamentais, identificando quais os aspectos envolvidos em sua classificação constitucional.

Há, indubitavelmente, a feição de garantia individual relacionada ao devido processo legal, já que é um elemento de competência funcional que serve de proteção à liberdade do indivíduo, determinando que, nos casos de crimes dolosos contra a vida, ele não pode ser condenado e apenado senão em razão de conclusão positiva de seus semelhantes.

Ingo Sarlet afirma, na esteira de Canotilho e Bonavides, que as garantias institucionais constitucionais em regra possuem natureza jurídico-objetiva e não são aptas a outorgar ao indivíduo direitos subjetivos autônomos ${ }^{19}$. Não é o caso do júri, como o próprio Sarlet destacou. Dada a complexidade histórica de formação e desenvolvimento da instituição, pode-se abstrair claramente desta garantia um direito subjetivo do acusado ao julgamento pelo júri.

Esta, inclusive, é a sua feição mais consagrada, revelando-se como um direito de o acusado ser julgado por seus pares, idealmente integrantes de uma mesma realidade social, econômica e cultural que a sua e que poderão - em tese - empreender um julgamento mais adequado à justiça esperada pela comunidade. Direito este, vale ressaltar, de aspecto preponderantemente positivo, já que impõe a adoção de ações estruturais pelo Estado para que assegure um mecanismo adequado de convocação e seleção de jurados, garantia do sigilo e da plena defesa, e construa um sistema recursal que prestigie sua soberania, mostrando sua feição negativa ao determinar uma inação do Estado-Juiz quanto à intervenção na definição meritória dos fatos.

Doutra banda, caso se compreenda o Tribunal do Júri apenas e tão somente pela feição fundamental do direito do cidadão de ser julgado por seus pares, pode-se chegar à conclusão, a que chegou Vladimir $\mathrm{Aras}^{20}$, de haver a possibilidade de renúncia deste direito pelo acusado

19 SARLET, Ingo Wolgang. A eficácia dos direitos fundamentais. Uma teoria geral dos direitos fundamentais na perspectiva constitucional. $11^{\mathrm{a}}$ ed. Porto Alegre: Livraria do Advogado, 2012.

20 ARAS, Vladimir. Renúncia ao julgamento pelo júri no Processo Penal Brasileiro. Waiver of jury trial in Brazilian Criminal Procedure. In: CALABRICH, 
e ele escolher ser julgado pelo juízo singular, o waiver of jury trial, como chamado no direito americano. Não é o caso.

$\mathrm{Na}$ feição democrática já exposta nos itens anteriores deste trabalho, o Tribunal do Júri também consolida um direito do cidadão, não acusado, de participar na administração da justiça do país ${ }^{21}$. Jeffrey Abramson também reforçava essa natureza dúplice do papel normativo do júri, ao afirmar que "a instituição é simultaneamente sobre direitos democráticos, políticos e participativos do cidadão de ser jurado, e também sobre o direito do acusado de encontrar no júri popular a melhor proteção contra a opressão $0^{22}$ ".

Perez Luño afirmava que os direitos fundamentais, em sua feição axiológica objetiva, representavam o resultado de um pacto entre as diferentes forças sociais, alcançado por relações de tensão e cooperação $0^{23}$. O Tribunal do Júri sempre esteve no epicentro das tensões entre autoritarismo e democracia, e seu ressurgimento e prestígio sempre foram historicamente vistos como uma vitória do povo, que passa a assumir diretamente, mesmo que de forma restrita, o poder de definir o padrão de conduta de sua própria comunidade.

Não há como negar que a previsão constitucional do Tribunal do Júri descortina um direito individual subjetivo de participação direta do cidadão na administração da justiça dos crimes dolosos contra a vida. Este, inclusive, é o principal elemento definidor do conteúdo normativo do direito ao Tribunal do Júri.

Desta conclusão se inicia a discussão acerca do conteúdo normativo da soberania dos veredictos. A partir do momento em que se

Bruno; FISCHER, Douglas; PELELLA, Eduardo (orgs.). Garantismo Penal Integral. $3^{\mathrm{a}}$ ed. São Paulo: Atlas, 2015.

21 Neste sentido: NUCCI, Guilherme de Souza. Júri: Princípios Constitucionais. São Paulo: Ed. Juarez de Oliveira, 1999; ALENCAR, Rosmar Rodrigues; TÁVORA, Nestor. Curso de Direito Processual Penal. 11ª ed. Salvador: Juspodivm, 2016.

22 "the institution is simultaneously all about the political, participatory, or democratic rights of citizens to be jurors, and yet all about the rights of the accused to find in the jury of the people the best protection against oppression" (ABRAMSON, Jeffrey. Op. cit.) (tradução nossa).

23 LUÑO, Antonio E. Perez. Los Derechos Fundamentais. Madrid: Tecnos, 1995, p. 21. 
determina o Tribunal do Júri como, essencialmente, um direito de o cidadão participar da administração da justiça, determinando diretamente, e não por intermédio do Estado, o destino dos integrantes de sua comunidade, é especialmente relevante que a decisão final tomada pelo povo seja constitucionalmente protegida da intervenção e modificação do Estado, contra quem a instituição originalmente fora criada. Não se poderia admitir qualquer legislação infraconstitucional que permitisse ao Poder Judiciário sobrepor sua vontade àquela adotada pelo conselho popular de sentença, sob pena de se atingir o núcleo essencial da soberania dos veredictos.

\subsection{RAZÕES E OS REFLEXOS DA OPÇÃO CONSTITUINTE PELA SOBERANIA DOS VEREDICTOS: EXTRAINDO SEU CONTEÚDO NORMATIVO}

No texto constitucional, a expressão soberania somente é utilizada em três oportunidades: ao se referir à soberania nacional como fundamento da república e merecedora de proteção institucional (arts. $1^{\mathrm{o}}$, I, $\S 5^{\circ}$, LXXI, $17,91,170$, I, e $231, \S 5^{\circ}$ ), a soberania popular exercida por meio do sufrágio universal (art. 14) e a soberania dos veredictos do Tribunal do Júri (art. 5º XXXVIII, c).

Certamente não se tratou de uma opção gramatical desimportante do Constituinte, especialmente se considerados o contexto histórico e os fundamentos democráticos de fortalecimento do Tribunal do Júri, já detalhadas neste artigo. Indubitavelmente, pretendeu-se, com esta provisão constitucional específica, relacionar diretamente o veredicto como uma expressão do poder do povo, já que é algo comparável ao voto e à república, e, ao mesmo tempo, conferir à decisão dos jurados uma força jurídiconormativa superior à das demais decisões do Estado-Juiz. Afinal, é uma decisão que não está sujeita a reforma sequer pela Suprema Corte do País.

Frederico Marques já alertava que a soberania dos veredictos é uma expressão técnico-jurídica "que deve ser definida segundo a ciência dogmática do processo penal, e não de acordo com uma exegese de lastro filológico, alimentada em esclarecimentos vagos de dicionários”24. Assim

${ }^{24}$ MARQUES, José Frederico. Op. cit. 
sendo, concorda-se com Nucci quando afirma que não se pode pretender estender ao júri toda a complexidade do tradicional conceito de soberania atrelado aos Estados-Nações em suas relações internacionais ${ }^{25}$.

O risco de se olhar para a soberania dos veredictos com a perspectiva do direito dos Estados é querer compreender o júri como algo supremo e absoluto, sem nenhuma sorte de controle pela legislação infraconstitucional, o que não parece condizente com a ideia de direitos fundamentais pretendida pelo Constituinte.

Em nosso ordenamento, a soberania não é alçada ao patamar absoluto que outrora lhe era concedido pelas fundamentações teológicas ou contratualistas. A confrontação da soberania dos veredictos com os demais direitos fundamentais do acusado acabou por gerar um sistema processual muito específico, em que, por vezes, a decisão tomada pelo Conselho de Sentença é objeto de revisão, prévia e posterior, pelo Poder Judiciário togado. E é importante que assim o seja, já que um poder livre de qualquer sorte de controles, mesmo que legitimado pelo povo, não se revelou como algo salutar na história da consolidação democrática.

Entretanto, eventual revisão nunca pode atingir o núcleo essencial do júri, que é a prevalência da vontade da comunidade sobre o interesse do Judiciário togado. Dessa forma, como se verá mais adiante, de nenhuma forma poderá a Corte Revisora anular o Tribunal do Júri por uma mera discordância da conclusão a que ele chegou, ou por uma diferente interpretação dos fatos, ou, eventualmente, imiscuir-se nas funções judicantes e proferir diretamente a decisão meritória em contrariedade à decisão do júri, como alguns defendem ser possível em revisão criminal. Para evitar a afetação a esta ratio essendi do Tribunal do Júri, entende-se imprescindível uma blindagem constitucional.

As ressalvas feitas à soberania são, em regra, atreladas a um descontentamento com a própria instituição do júri e a "atecnicidade" do julgamento, que geraria muitas absolvições por clemência induzida mediante um sentimentalismo construído artificialmente pelas defesas dos acusados. Concorda-se com Lênio Streck quando ele afirma que algumas críticas usualmente se relacionam com certo grau de fetichismo com o cientificismo, como se a técnica dogmático-jurídica fosse o único

25 NUCCI, Guilherme de Souza. Op. cit. 
mecanismo legítimo para se conferir um status de dignidade e verdade às decisões penais ${ }^{26}$.

As decisões dos jurados, embora tomadas por íntima convicção e não sujeitas à motivação expressa, obtém sua legitimidade e dignidade a partir da democratização da administração da justiça, fundada no direito subjetivo de o cidadão participar na definição dos padrões de conduta de sua comunidade. Esta definição pode implicar uma absolvição quando os elementos de convencimento possam conduzir a uma condenação. Muitas vezes pode haver uma discordância entre o que os jurados decidem e o que decidiria um Magistrado togado, mas se não fosse para assim sê-lo, a instituição perderia a razão de ser. Quisesse o Constituinte que o júri decidisse sempre da mesma forma que o Magistrado, não o teria revitalizado e fortalecido.

Dogmaticamente, então, a soberania se traduz essencialmente numa competência jurídico-funcional conferida ao júri para dar a última palavra acerca dos fatos apurados e da responsabilidade criminal daqueles acusados de atentar dolosamente contra a vida de outrem, e de impor seu padrão de conduta para aquela comunidade, através do poder simbólico (veritas e auctoritas) daquela decisão jurídica. Ela obsta que qualquer medida legislativa ou judicial seja adotada com o intuito de transferir ao Estado esta parcela de poder que constitucionalmente foi direcionada ao cidadão.

De tudo que foi dito e analisado neste capítulo, vê-se claramente que a soberania dos veredictos, porquanto intimamente ligada com os fundamentos e justificações do Tribunal do Júri, é uma norma constitucional de natureza dúplice: a garantia do cidadão julgado de ter assegurado e protegido seu direito de ter seu destino decidido por seus iguais, e o direito do povo de participar na administração da justiça, assumindo diretamente parcela de poder, consistente no julgamento dos atos dolosos contra a vida, agindo para a fixação dos padrões de conduta de sua comunidade.

Como os outros direitos constitucionais, a soberania dos veredictos não possui natureza absoluta. Como observou Chaves, "o Tribunal do Júri brasileiro deve compatibilizar com o modelo democrático" e “a

26 STRECK, Lênio. Op. cit. 
soberania dos vereditos deve ser lida aos olhos da Constituição" ${ }^{27}$, de modo que seu confronto com princípios caros ao Estado Democrático, como presunção de inocência, plena defesa e duplo grau de jurisdição, permite a construção de um sistema processual em que haja controle prévio e posterior pelo Poder Judiciário, embora, novamente, este controle não atinja o mérito essencial dos veredictos nem substitua a vontade popular pela do Estado.

Em sendo, como visto, a soberania dos veredictos um elemento normativo constitucional que confere alto grau de imutabilidade às decisões dos jurados, preserva uma capacidade de o povo exercer diretamente parcela de seu poder e exclui do Judiciário a possibilidade de reforma direta sobre seu conteúdo, é importante que se analise de que forma isso se reflete no procedimento específico previsto em lei para o Tribunal do Júri.

Nesta perspectiva, nosso sistema acertadamente criou mecanismos de controle prévio da decisão dos jurados, estabelecendo uma primeira fase de instrução probatória perante o Juiz togado (judicium accusationis), quando então ele deverá filtrar as acusações levianas, as manifestamente infundadas e os casos claros de excludentes legais, e uma segunda fase diretamente perante o juízo natural da causa (judicium causae), quando o mérito da acusação será enfim resolvido.

Criou-se, ainda, uma possibilidade de análise superveniente do veredito soberano, através de um sistema recursal peculiar que permite, entre outras possibilidades, uma incursão superficial no mérito fático-probatório para se verificar decisões completamente desprovidas de fundamentos.

O impacto da soberania dos veredictos, portanto, é perceptível em todo o procedimento do júri, devendo ser avaliadas minuciosamente estas formas de controle prévio e superveniente de modo a identificar a possibilidade de formação de uma coisa julgada parcial que possa influenciar na decisão acerca do momento inicial de cumprimento da pena.

27 CHAVES, Charley Teixeira. O povo e o Tribunal do Júri. Belo Horizonte: D’Plácido, 2015, p. 339. 


\section{O SISTEMA RECURSAL COMO CONTROLE POSTERIOR E O LIMITE DA DEVOLUTIVIDADE RECURSAL EM FACE DAS CONDENAÇÕES IMPOSTAS PELO TRIBUNAL DO JÚRI}

Após a preclusão da decisão de pronúncia, o réu é submetido ao julgamento popular. Neste momento, será proferida, pelo juiz presidente, a sentença absolutória, desclassificatória ou condenatória, a depender do resultado da votação do conselho de jurados. Observa-se, claramente, que a sentença condenatória final é um instrumento decisório obtido da combinação de vontades de um órgão julgador colegiado, cuja competência é constitucional e legalmente definida, impassível de confusão.

Ao Conselho de Sentença cabe a decisão sobre o mérito da acusação, definindo se condena, absolve ou desclassifica a acusação formulada pelo Ministério Público, e ao Juiz-Presidente cabe aplicar a decisão dos jurados, decidindo, se necessário, acerca do processo de dosimetria da pena. Diz-se que ela é uma decisão subjetivamente complexa ${ }^{28}$, já que advém de um órgão colegiado heterogêneo e horizontal.

As decisões integram um mesmo ato judicial por sua interdependência objetiva (a dosimetria deve ser realizada nos estritos limites dos fatos reconhecidos pelo júri), mas são expressões de distinta cognição, pois os jurados analisam as provas para definir a existência do fato e a culpa do indivíduo, enquanto o Juiz parte da culpa reconhecida para mensurar a extensão da pena.

Embora integrantes de um único ato judicial, as decisões nela contidas possuem natureza diversa e estão sujeitas a impugnações específicas, segundo critérios estabelecidos pela legislação processual, o que acaba por gerar, necessariamente, momentos preclusivos distintos. O artigo 593, inciso III, do CPP estabelece que os fundamentos com os quais o acusado pode se insurgir contra a condenação do júri são: a) nulidade posterior à pronúncia; b) sentença do juiz-presidente contrária à lei expressa ou à decisão dos jurados; c) erro ou injustiça na aplicação da pena; d) decisão dos jurados manifestamente contrária às provas dos autos.

As alíneas a, b e c, portanto, referem-se à parte da decisão, ou do processo, que coube ao Juiz togado, enquanto a alínea d é pertinente

28 ALENCAR, Rosmar Rodrigues; TÁVORA, Nestor. Op. cit. 
ao capítulo da decisão que foi fruto da deliberação dos jurados. É consolidada a jurisprudência nos Tribunais Superiores no sentido de que a devolutividade das apelações do júri é adstrita aos fundamentos da interposição ${ }^{29}$, não podendo a Corte Recursal analisar matéria acerca da qual não houve insurgência da parte recorrente.

Isso porque, em sendo a decisão dos jurados constitucionalmente soberana, não poderia a Corte Revisora sobre ela decidir sem que tenha havido impugnação da parte prejudicada, sob pena de se violar precisamente esta soberania, já que se estaria suplantando a decisão popular pela do Estado, sem nenhuma provocação de sua jurisdição. Lembra-se: o duplo grau de jurisdição é um direito, não um dever. Vê-se, portanto, uma distinção das apelações criminais tradicionais em que não há esta salvaguarda constitucional, e, por conseguinte, as insurgências se revestem de ampla devolutividade, submetendo-se toda a matéria decidida à revisão dos Tribunais.

A discussão acerca da soberania dos veredictos surge, portanto, apenas na quarta hipótese recursal, referente à decisão manifestamente contrária às provas dos autos, já que se cuida de uma provocação à Corte Superior para que revisite o mérito da acusação e das provas e realize um juízo de valor acerca da decisão do Tribunal do Júri. Entretanto, por força do direito-garantia da soberania, e de tudo que ela implica, decerto que a atuação da Corte Revisora enfrenta limites cognitivos, sendo, a anulação do julgamento com base em seu mérito, verdadeiramente uma exceção, apenas cabível "naquelas situações absolutamente incontestáveis nas quais a decisão dos jurados desbordou de toda prova existente nos autos"30.

A jurisprudência vem seguindo esta linha e tem cuidado da anulação da decisão dos jurados como medida extrema, praticamente com uma finalidade rescisória, já que não enfrenta discordância de valoração ou interpretação, mas apenas ausência completa de provas que sustentem a decisão e não permite a reforma do julgado, apenas a sua anulação e devolução para novo julgamento popular.

29 Destaca-se o teor do enunciado no. 713, da Súmula do STF: "O efeito devolutivo da apelação contra decisões do júri é adstrito aos fundamentos da sua interposição",

30 PACELLI, Eugênio; FISCHER, Douglas. Op. cit., p. 1.205. 
Em pesquisa realizada em programa de Mestrado da Universidade Federal de Alagoas, pudemos analisar o resultado das 597 apelações interpostas contra decisões do Tribunal do Júri no Estado de Alagoas entre 2013 e 2017. Destas, 470 eram relativas a condenações, tendo se verificado que o Tribunal competente, neste intervalo de 5 anos, anulou apenas 34 júris, o equivalente a $7 \%$ das condenações recorridas ${ }^{31}$.

Apenas em um cenário de banalização da decisão de pronúncia pelo Judiciário togado, e pela equivocada compreensão de seu papel, poder-se-ia chegar a uma condenação que não encontra nenhum amparo nas provas dos autos. É um cenário bastante comum, digase de passagem, razão pela qual os mecanismos de controle ulterior são essenciais. Todavia, é uma constatação que pode vir a explicar os baixos números de provimento de recursos fundamentados neste argumento.

Não se deve esquecer que o sistema jurídico já coloca à disposição do acusado toda a estrutura das quatro instâncias do Poder Judiciário ainda na primeira fase do Tribunal do Júri, mesmo que nessa fase a análise tenda a ser superficial e orientada pela criticável lógica do in dubio pro societate. Não se critica, contudo, essas possibilidades recursais de primeira fase. Os mecanismos de controle prévio, especialmente a decisão de pronúncia, são de extrema importância, já que é "imprescindível que o feito chegue a julgamento popular fortalecido por um procedimento complexo que permita um controle prévio efetivo de questões técnicas que podem escapar à compreensão dos jurados leigos"32.

Após esta digressão revisora das normas procedimentais do júri, e definidos os limites da devolutividade recursal, imperioso que se analise de que forma as peculiaridades do sistema de controle posterior da decisão do júri impactam na formação da coisa julgada.

31 RODRIGUES, Paulo Gustavo Lima e Silva. Os efeitos da soberania dos veredictos na definição do momento inicial de cumprimento das penas impostas pelo Tribunal do Júri. 2018. Dissertação (Mestrado em Direito Público). Faculdade de Direito da Universidade Federal de Alagoas, Maceió, 2018. Disponível em: http://www.repositorio.ufal.br/handle/riufal/3250.

32 RODRIGUES, Paulo Gustavo. A imprescindibilidade das instâncias de controle prévio da decisão do Tribunal do Júri: crítica à medida II do pacote anticrime. In: Boletim IBCCRIM. Ano 27. N. 317. Abril/2019. 


\section{REDEFININDO O TRÂNSITO EM JULGADO PENAL A PARTIR DA SOBERANIA DOS VEREDICTOS: A COISA JULGADA PARCIAL NO TRIBUNAL DO JÚRI}

A coisa julgada é um dos institutos jurídicos mais relevantes para o direito, seja por seu papel na garantia da segurança jurídica, seja pela necessidade de sua estabilidade para conferência de legitimidade e força à atuação estatal. Diz Jordi Nieva-Fenoll que "se a coisa julgada não existisse em um ordenamento jurídico, haveria que inventá-la, porque é perfeitamente imaginável a insegurança jurídica que se derivaria da sua inexistência"33.

Não houvesse estabilidade das decisões jurídicas, "ninguém saberia ao que se ater, e finalmente, deixaria de existir o aparato da justiça, vez que ninguém se socorreria dele para resolver seus problemas" ${ }^{34}$, de modo que o objetivo da coisa julgada não é simplesmente a proteção do acusado ou do réu, e sim de toda a sociedade, que se vê em risco em face da possibilidade de mutação eterna dos juízos.

No processo penal, embora a coisa julgada assuma um papel essencial de garantia do acusado ${ }^{35}$, igualmente é uma proteção da funcionalidade estabilizadora do sistema penal. Parte-se do pressuposto de que, embora os conflitos sociais possam assumir uma relativa perenidade, os conflitos processuais devem chegar a um fim, caso contrário não haveria mais qualquer confiabilidade social no aparato da justiça.

Muitas são as teorias que buscam fundamentar ou justificar a coisa julgada, desde teorias político-linguísticas a teorias jurídicas como a da ficção da verdade, presunção da verdade, força legal da sentença, eficácia da declaração ou teoria do quase contrato judicial ${ }^{36}$, cujos desenvolvimentos não são pertinentes a este trabalho, mas que se indicam apenas como demonstração da complexidade do desenvolvimento dogmático acerca do tema.

33 NIEVA-FENOLL, Jordi. Coisa julgada. Trad.: Antônio do Passo Cabral. São Paulo: RT, 2016, p. 89.

34 Ibidem, p. 90.

35 RANGEL, Paulo. A coisa julgada no processo penal brasileiro como instrumento de garantia. São Paulo: Atlas, 2012.

36 Ibidem. 
Fosse este um conceito jurídico genuíno, na definição de Ale$\mathrm{xy}^{37}$, sua mudança implicaria uma proposta de mudança das normas a que se refere, o que não é o caso. A ideia de coisa julgada está presente em diversas normas jurídicas, mas não é por elas delimitado em toda a sua extensão, embora o novo Código de Processo Civil traga o conceito genérico de coisa julgada material como a autoridade que torna imutável e indiscutível a decisão de mérito não mais sujeita a recurso.

Desde logo destaca-se a filiação à tese de que, embora a expressão trânsito em julgado seja algo próprio das sentenças, não só a elas se confere efeitos estabilizadores. Independentemente de ser decisão interlocutória, sentença ou capítulo de sentença, é inegável que "qualquer decisão judicial pode ter efeitos de coisa julgada se contém pronunciamentos que requeiram estabilidade" 38 , como é o caso das decisões do Tribunal do Júri em razão do mandamento constitucional da soberania dos veredictos e das peculiaridades do sistema recursal.

A partir do momento em que não há impugnação, ou não há possibilidade legal de impugnação, acerca de determinado elemento da sentença condenatória do júri, ele se reveste dos efeitos da coisa julgada, adquire estabilidade e se torna impassível de reexame ou desvirtuação por juízo posterior. Badaró destaca acertadamente que a coisa julgada se dá tanto pelo esgotamento das vias recursais quanto pelo decurso in albis do prazo recursal ${ }^{39}$. Vale dizer, o duplo grau de jurisdição, longe de ser um dever, é um direito, de modo que não havendo insurgência, pelas partes, contra a decisão meritória do júri, ela transita em julgado formal e materialmente, independente do prosseguimento do feito em relação às impugnações quanto às decisões do juiz presidente.

Não se está a falar que isso ocorre com frequência ou em todos os casos. A interposição de apelação alegando nulidade posterior à pronúncia (art. 593, III, a), por exemplo, não permite tal efeito, já que, a princípio, tem potencial para afetar toda a sessão de julgamento, sindicando tanto

37 ALEXY, Robert. Teoria da argumentação jurídica: a teoria do discurso racional como teoria da fundamentação jurídica. Trad.: Zilda Hutchinson Schild Silva. $3^{\mathrm{a}}$ ed. Rio de Janeiro: Forense, 2011, p. 252.

NIEVA-FENOLL, Jordi. Op. cit., p. 196.

39 BADARÓ, Gustavo Henrique. Processo Penal. $3^{\text {a }}$ ed. São Paulo: Editora Revista dos Tribunais, p. 547. 
a decisão do Juiz quanto a dos jurados, não havendo, ainda, estabilidade apta a conferir-lhe o status de coisa julgada. Da mesma forma, ao se alegar que a decisão do juiz foi contrária à lei ou à decisão dos jurados (art. 593, III, b), a contradição interna da sentença conjunta impede a formação da coisa julgada, pela necessidade de esclarecimento efetivo de seu conteúdo, para lhe conferir estabilidade.

Nos casos que se passa a abordar, a soberania dos veredictos e a formulação legal do sistema recursal impedem as Cortes Revisoras de virem a analisar o mérito da condenação para reformá-lo ou anulá-lo, de modo que resta indubitável o reconhecimento dos efeitos da coisa julgada, mesmo que sobre capítulos específicos da sentença e não sobre ela como um todo.

Como um exemplo claro de hipótese em que a soberania dos veredictos consolida uma coisa julgada parcial, traz-se o caso de apelações interpostas com fundamento exclusivo de revisão de dosimetria.

Nesses casos, o capítulo da sentença atinente à culpa do réu - aqui entendida como reconhecimento de responsabilidade criminal pelo fato denunciado -, fruto de um veredito constitucionalmente soberano, não foi objeto de impugnação recursal pela parte condenada, que se limitou a questionar a atividade do Juiz e sua dosimetria. A soberania dos veredictos, como mandamento constitucional que impõe insindicabilidade à decisão dos jurados, funcionaria como elemento limitador de atuação da Corte Recursal, não podendo ela anular a condenação, uma vez que se trata de parte soberana da decisão, que não foi impugnada pela parte prejudicada.

Estando a coisa julgada intimamente ligada, no processo penal, à regra do ne bis in idem, Badaró afirma que ela implica uma estabilidade e uma imutabilidade dos fatos naturalísticos discutidos nos autos, em sua inteireza, independentemente da qualificação jurídica que lhe é dada ${ }^{40}$. Deste modo, evidenciando-se uma impossibilidade de atuação da Corte Recursal acerca daqueles fatos julgados pelo júri, é inegável que se confere à condenação do réu um status de coisa julgada parcial, mesmo que sui generis no Processo Penal.

Os fatos decididos soberanamente pelo júri transitam em julgado, uma vez que não podem legalmente ser objeto de revisão, passando

40 BADARÓ, Gustavo Henrique. Op. cit., p. 549. 
a vincular quaisquer decisões futuras acerca do caso, no mesmo ou em outros processos.

Este efeito preclusivo decorrente do trânsito em julgado não pode ser mitigado pela Corte de Apelações mesmo que esta venha a discordar da decisão dos jurados, já que, como disse Nicolitt, "a sentença pode ser justa ou injusta, mas uma vez esgotada a possibilidade de ser atacada por recurso, passa a ser a manifestação da verdade, por força da coisa julgada” ${ }^{41}$, sendo este o caso quando não há insurgência contra a condenação decidida pelos jurados.

Com tal conclusão, havendo condenação do Tribunal do Júri e sendo a apelação interposta fundamentada exclusivamente em suposto equívoco da dosimetria, não haveria nenhum impedimento para se determinar o imediato início do cumprimento da pena, já que há um reconhecimento judicial com força de coisa julgada reconhecendo a culpa do réu, o que nem sequer implicaria uma relativização ou mitigação do princípio da presunção de não culpabilidade em sua interpretação literal.

Outro caso legalmente regulamentado também oferece uma hipótese de coisa julgada parcial no procedimento especial do júri. Dada a natureza sui generis destas apelações criminais, necessariamente o provimento do recurso implica a realização de um novo julgamento, e não simplesmente a prolação de nova decisão. Qualquer hipótese normativa que implicasse a substituição da decisão popular pela de um Juiz ou Tribunal togado implicaria violação direta da própria ratio essendi normativo-constitucional do Tribunal do Júri e da soberania dos veredictos, como já visto no primeiro capítulo.

Observa-se claramente, então, que a realização de um novo julgamento implica a instauração da possibilidade de uma nova apelação. Contudo, para evitar a interposição sucessiva e protelatória de novos recursos, virtualmente infindáveis, o Código de Processo Penal trouxe uma disposição proibitiva de segundo apelo idêntico em face de julgamento refeito. Diz o parágrafo terceiro do artigo 593 que não se admite segunda apelação pelo mesmo motivo quando o julgamento foi anulado pela Corte Revisora.

41 NICOLITT, André. Manual de Processo Penal. 6a ed. São Paulo: Editora Revista dos Tribunais, 2016, p. 901. 
Na hipótese de um réu ter sido absolvido em seu primeiro julgamento e o Ministério Público ter recorrido ao Tribunal de Justiça, caso os Desembargadores entendam não haver algum vestígio de prova que sustente a decisão absolutória dos jurados, devem submetê-lo a novo Tribunal do Júri. A partir do momento que o acórdão transita em julgado, já há uma manifestação meritória definitiva da Corte de Apelações no sentido da inadmissibilidade de um veredito absolutório, de modo que caso o réu seja condenado pelo segundo conselho de sentença, a defesa não poderia mais interpor apelação alegando decisão manifestamente contrária às provas dos autos, sob pena de violar a coisa julgada da primeira apelação. A igual conclusão se chega nas hipóteses de condenações anuladas convertidas em absolvições.

Outra discussão surge, entretanto, quando um Tribunal de Apelação reconhece que determinada absolvição/condenação foi manifestamente contrária às provas dos autos, e um novo júri, formado por outras sete pessoas, insiste naquela decisão. Neste caso é possível observar precisamente o papel da soberania dos veredictos como estabilizadores dos efeitos das decisões.

Diz Badaró que "seria inviável admitir a cassação de forma ilimitada, até que o julgamento do júri se conformasse à decisão do Tribunal de Justiça" ${ }^{42}$. Caso fosse permitida a interposição sucessiva de novas apelações, e júris fossem sendo insistentemente refeitos por ordem de juízes togados, criar-se-ia uma hipótese em que o Poder Judiciário anularia tantos júris quantos fossem necessários para fazer valer sua decisão, o que não é compatível com o direito-garantia da soberania dos veredictos, que impõe a decisão final acerca dos crimes dolosos contra a vida ao povo, não ao Estado.

Desta forma, em sendo realizado um segundo julgamento e o veredicto venha a ser condenatório, a legislação impõe um óbice claro e definitivo à interposição de novo recurso, de modo que deve haver a determinação de início imediato do cumprimento da pena ante ao impedimento legal de revisão da conclusão fático-probatória dos jurados acerca da culpa do acusado, início este que deve ser obstado apenas em face de alegações recursais de nulidades ou conflito interno de decisões.

42 BADARÓ, Gustavo Henrique. Op. cit., p. 839. 
A controvérsia surgiria na definição de que pena ele teria de cumprir, já que o quantum ainda estaria sendo discutido em grau recursal. Em havendo impugnação contra o processo de dosimetria, seria ele um capítulo da sentença que não estaria atingido pelos efeitos da coisa julgada parcial que ora se defende, de modo que o Magistrado que determinar a execução imediata da sentença nestas hipóteses deverá levar em consideração tal circunstância na fundamentação de sua decisão.

Contudo, tendo-se como definitiva a condenação do réu pelo crime de homicídio, por exemplo, também é evidente que o processo de dosimetria não poderia conduzir a pena para aquém de mínimos legalmente estabelecidos, de modo que tampouco este patamar de piso pode ser afetado pela decisão recursal. Poder-se-ia, então, considerar como transitada em julgado a condenação do réu por aquele crime à pena mínima, utilizando-se este indicador como referência para cálculo dos benefícios da execução, enquanto tramitam seus recursos.

Em síntese, dada a imutabilidade legal deste capítulo da decisão (condenação), e a impossibilidade de outro Juiz ou júri rever seu mérito, estas duas hipóteses (recurso exclusivo de dosimetria e condenação após julgamento refeito) evidenciam claramente a formação de uma coisa julgada parcial desde a primeira instância, atinente à responsabilidade criminal do indivíduo pelo fato processado, já que a culpa do réu (parte meritória da decisão, de responsabilidade do corpo de jurados) legalmente não pode mais ser objeto de impugnação.

\subsection{A COISA JULGADA PARCIAL A PARTIR DA CONFIRMAÇÃO DA CONDENAÇÃO EM SEGUNDA INSTÂNCIA}

As duas primeiras hipóteses até aqui abordadas fornecem fundamentação jurídica apta a determinar, nestes casos específicos, o início de cumprimento da pena imposta pelo Tribunal do Júri desde a condenação em primeira instância, uma vez que nela precluiria a análise fático-probatória e a decisão acerca da culpa do réu se revestiria dos efeitos do trânsito em julgado. Entretanto, com a construção da ideia de uma coisa julgada parcial ante a impossibilidade legal de revisão da conclusão meritória soberana do conselho de jurados, mostra-se lógica a conclusão de que também é possível o início de cumprimento 
de pena após a confirmação da condenação em segunda instância, para os demais casos.

É indiscutível que, nos dispositivos relativos ao sistema recursal brasileiro, a Constituição destituiu o Superior Tribunal de Justiça - STJ e o Supremo Tribunal Federal - STF do papel de terceira e quarta instância revisora, relegando a eles o papel de uniformizadores da interpretação de leis federais e da Constituição, com recursos destinados apenas a discussões jurídicas, sem possibilidade de reavaliação ou reforma das conclusões fático-probatórias alcançadas pelas instâncias inferiores, alçando-os à condição de Cortes Supremas, segundo acertadamente concluiu Daniel Mitidiero ${ }^{43}$. Diz ainda Nicolitt que "o objetivo destes recursos é assegurar a autoridade e a uniformidade na aplicação e interpretação da Constituição [...] e das leis federais" ${ }^{44}$.

Tal questão se reforçaria com a incorporação, ao processo interpretativo, do art. $102, \S 3^{\circ}$, da Constituição, que teria criado o requisito da repercussão geral para o conhecimento dos recursos extraordinários, fortalecendo a tese de que a Constituição não pretendeu o Supremo Tribunal Federal como revisor de equívocos específicos cometidos nas instâncias inferiores (igual dispositivo está em via de aprovação no Congresso Nacional, para os recursos especiais ${ }^{45}$ ).

Com esse requisito, mesmo que o Supremo Tribunal Federal verifique a incorreção ou injustiça de alguma decisão, ele não poderia conhecer do recurso extraordinário para intervir no caso quando não demonstradas a relevância e a transcendentalidade da matéria, ou seja, quando não provado que aquela decisão serviria a um propósito jurídico uniformizador que supere a necessidade do caso concreto, o que geralmente não ocorre nos casos penais em que se discute a responsabilidade criminal de um indivíduo específico.

43 MITIDIERO, Daniel. Cortes Superiores e Cortes Supremas: do controle à interpretação, da jurisprudência ao precedente. $3^{\mathrm{a}}$ Ed. São Paulo: RT, 2017.

44 NICOLITT, André. Op. cit., p. 957.

45 Trata-se do Projeto de Emenda à Constituição nº 209/12, aprovado em dois turnos na Câmara dos Deputados e enviado ao Senado Federal, conforme se vê em noticiários virtuais como: <https://www.conjur.com.br/2017-mar-16/ pec-cria-filtro-recurso-especial-aprovada-camara>. Acesso em 6.3.2018. 
Este fora, inclusive, um dos fundamentos invocados pelo Supremo Tribunal Federal para justificar sua decisão de ampla e irrestrita execução provisória da pena após confirmação em segunda instância no HC 126.292/SP: a consolidação da discussão fático-probatória no julgamento das apelações criminais ${ }^{46}$.

Mitidiero entende ser incorreto dizer que as Cortes Supremas (como seria o caso do STJ e do STF) não examinam fatos, já que o caso submetido à sua decisão "depende de uma sólida e recíproca influência entre fatos e normas, o que denota a unidade fático-normativa da causa" ${ }^{47}$. Segundo o autor, o que se proíbe é que as Cortes Supremas realizem novas valorações probatórias das alegações de fato, vale dizer, eles analisam efetivamente os fatos, mas pressupondo a valoração probatória realizada pela instância ordinária, utilizando ela como premissa para sua análise do Direito e formação do precedente ${ }^{48}$.

Com base neste raciocínio, diferencia a análise de fatos realizada pelos Tribunais de Apelação e pelas Cortes Supremas não sob uma perspectiva ontológica, mas teleológica, referente às funções desempenhadas por cada Tribunal no Estado Constitucional ${ }^{49}$. Nesta lógica, o autor busca construir a ideia de que a causa transita em julgado na segunda instância (já que nela são definidas todas as premissas fáticas impassíveis de reavaliação probatória), enquanto os recursos às Cortes Supremas se destinam ao trânsito em julgado do precedente.

Entretanto, como regra geral, esta é uma conclusão que pode trazer incongruências a certas situações no Processo Penal, razão pela qual não se defende, neste artigo, a possibilidade irrestrita de execução de condenações criminais na segunda instância - no que tange aos crimes em geral. Isso porque, a responsabilização criminal de um indivíduo não depende única e exclusivamente da avaliação dos fatos, havendo também discussões jurídicas que se mostram extremamente relevantes para o estabelecimento das premissas de cumprimento da

\footnotetext{
46 BRASIL. Supremo Tribunal Federal. Acórdão no HC 126.292/SP. Tribunal Pleno. Relator Ministro Teori Zavascki. Julgado em 19.2.2016. 
pena. Em muitos casos, a própria ocorrência do crime depende da solução de uma controvérsia puramente jurídica, como nos processos em que há divergência acerca da tipicidade de determinada conduta faticamente incontroversa.

Ademais, a devolutividade ampla dos recursos criminais em geral não autoriza a compreensão de preclusão de qualquer parcela do processo, mesmo aquelas que não foram objeto de impugnação específica da parte, de modo que a forma com que o sistema processual hoje se encontra construído, não há como se verificar uma antecipação do trânsito em julgado nos procedimentos ordinários.

O que diferencia o procedimento do júri, e que justifica a adoção desta ideia como regra para a consolidação de uma coisa julgada na segunda instância, é precisamente a duplicidade de suas fases, o que acaba por criar um contexto em que as eventuais discussões jurídicas atinentes à tipicidade do caso são solucionadas já na fase da pronúncia que, repise-se, pode ser analisada por todas as instâncias recursais do nosso sistema de justiça.

Dessa forma, havendo julgamento da apelação criminal, há consolidação da discussão fático-probatória, que não poderá ser levada, por qualquer hipótese recursal constitucional, à reavaliação dos Tribunais Superiores, de modo que há estabilidade plena para o capítulo da decisão referente à culpa do réu, podendo-se falar em coisa julgada apta a justificar o início de cumprimento da pena.

Igual conclusão pode ser construída por uma interpretação sistêmica dos dispositivos constitucionais em estudo, pois, como visto, a estrutura do sistema recursal do Tribunal do Júri conduz à conclusão de uma completa inocuidade e imprestabilidade dos recursos excepcionais para rever as premissas que fundamentam a culpa do indivíduo, de modo que não há lógica em um mesmo texto constitucional obstar o cumprimento da pena em razão de insurgências recursais que o próprio texto constitucional destituiu da habilidade de rever seu fundamento.

Inclusive, vale ressaltar que na pesquisa de mestrado já referenciada, verificamos que, entre 2013 e 2017, nenhum dos recursos especiais e extraordinários efetivamente encaminhados às Cortes Superiores pelo TJAL foi provido para se anular sessão (condenatória ou absolutória) de 
Tribunal do Júri, havendo apenas casos de provimento para redimensionar pena ou para restabelecer júri anulado pela segunda instância. ${ }^{50}$

Com essa peculiaridade em mente, pode-se chegar à seguinte conclusão: por que razão a Constituição preservaria o direito de o acusado evitar o cumprimento de uma condenação soberana imposta pelo júri, quando os Tribunais Superiores não teriam competência constitucional para rever seu mérito? Nos casos em que não há matéria jurídica relevante em discussão (como, repise-se, alegações de nulidades processuais ou conflito interno de decisões), não há coerência entre os modais deônticos oriundos das interpretações destes artigos.

Neste raciocínio, oriundo do contexto específico das condenações do júri, em que há um duplo grau interlocutório e uma limitação da devolutividade recursal derivada da soberania dos veredictos, observa-se uma contradição sistêmica entre a interpretação tradicional da presunção de não culpabilidade e o sistema recursal constitucional das Cortes Superiores, sendo solucionado apenas com a permissividade geral de início de cumprimento da pena após a confirmação em segunda instância, quando a matéria fático-probatória pode, ainda, ser objeto de análise, mesmo que superficial.

Enfim, conclui-se que a partir do reconhecimento da sentença condenatória do Tribunal do Júri como sendo uma decisão subjetivamente complexa, formada pela conclusão de dois julgadores distintos (os jurados quanto à condenação e o juiz quanto à pena), e de que estes elementos possuem momentos distintos de preclusão, não é difícil perceber como tal aspecto repercutiria na definição do momento inicial de cumprimento da pena.

Para se chegar a esta conclusão, não haveria sequer a necessidade de se superar a literalidade do art. 283 do CPP ou o princípio da presunção de não culpabilidade. Vale dizer, se ninguém pode ser considerado culpado (ou preso) até o trânsito em julgado de sentença penal condenatória, a partir do momento em que a condenação imposta pelo júri não é passível de revisão por qualquer outro juiz (em recursos exclusivos de dosimetria, julgamentos refeitos ou confirmação em segunda instância), o capítulo da sentença pertinente ao reconhecimento de sua responsabilidade penal

50 RODRIGUES, Paulo Gustavo Lima e Silva. Op. Cit., p. 89. 
pelo fato adquire estabilidade preclusiva, de modo que o réu passa a ser dogmática e constitucionalmente considerado culpado, podendo, em decorrência desta conclusão, iniciar o cumprimento de sua pena.

Não se trata, como acertadamente criticou Fauzi Choukr quanto à decisão do STF, de "condicionar o duplo grau de jurisdição às espécies de efeitos que determinados recursos possuem" "51, mas de reconhecer que, ao não recorrer da parcela da decisão que coube aos jurados soberanos (recurso de dosimetria) ou ao não ser mais legalmente possível a anulação meritória desta decisão (julgamento refeito e confirmação em grau de apelação), a decisão soberana se reveste de força de coisa julgada, podendo, então ser, regularmente executada.

Como toda regra geral, obviamente que pode haver exceções, notadamente nos casos de recursos especial ou extraordinário que apresentem discussão jurídica com a potencialidade de eventualmente anular a sessão de julgamento ou permaneça questão de divergência interna na decisão dos julgadores (togado e leigo), hipótese em que esta eficácia preclusiva não se verificará em qualquer dos capítulos, sendo premente a espera da manifestação das Cortes Supremas.

Assim, a partir de uma construção dogmático-processual de reformulação do conceito de coisa julgada e de uma interpretação sistêmica do texto constitucional, chega-se à conclusão de que também a confirmação em segunda instância configura fundamento legal e constitucionalmente adequado ao início de cumprimento das penas impostas pelo Tribunal do Júri.

Poder-se-ia alegar uma contradição interna na construção da presente tese pois se estaria reduzindo o campo de eficácia de direitos fundamentais do réu (presunção de inocência e ampla defesa) em razão de a ele ser atribuído outro direito-garantia fundamental (o Tribunal do Júri). Vale dizer, a concessão de um direito estaria implicando na redução de outro, dito mais importante.

Esta contradição é apenas aparente, por dois motivos. Inicialmente, o Tribunal do Júri e a soberania dos veredictos, como já dito, não é um direito-garantia de titularidade apenas dos réus. A bem da verdade, por nossa compreensão já exposta, o principal conteúdo normativo do

${ }^{51}$ CHOUKR, Fauzi Hassan. Op. Cit., p. 1132. 
Júri é o direito individual e subjetivo do cidadão de participar diretamente na tomada de decisões acerca da responsabilidade criminal dos que atentem contra a vida.

Essa eficácia normativa que é praticamente inutilizada quando se condiciona a execução da decisão à manifestação (virtualmente) inesgotável de todas as instâncias do Judiciário togado, contra o qual, justamente, ela foi criada e fortalecida pelo Poder Constituinte Originário.

Ademais, não se está dispensando a exigência de trânsito em julgado para a execução das penas, mas apenas propondo-se uma rediscussão acerca da existência de coisa julgada parcial no processo penal do Tribunal do Júri, a partir da ideia de momentos preclusivos distintos para os capítulos da condenação e da dosimetria.

\section{As MODIFICAÇÕES PROMOVIDAS PELA LEI Nº. 13.964/2019}

No último dia 24 de janeiro de 2020 , entrou em vigor a Lei $\mathrm{n}^{\circ}$. 13.964/2019, chamada Lei Anticrime, a qual, dentre diversas outras reformas, modificou os dispositivos referentes ao Tribunal do Júri para determinar a execução imediata das penas impostas em patamar igual ou superior a 15 (quinze) anos de reclusão.

Criou-se exceção de efeito suspensivo quando se verificasse, cumulativamente, "que o recurso [...] não tem propósito meramente protelatório e [...] levanta questão substancial e que pode resultar em absolvição, anulação da sentença, novo julgamento ou redução da pena para patamar inferior a 15 (quinze) anos de reclusão"52.

Estas modificações foram apontadas como inconstitucionais por doutrinadores como Alexandre Moraes da Rosa, Aury Lopes Jr. ${ }^{53} \mathrm{e}$

52 BRASIL. Lei no ${ }^{\circ}$ 13.964, de 24 de dezembro de 2019. Disponível em: http:// www.planalto.gov.br/ccivil_03/_Ato2019-2022/2019/Lei/L13964.htm

53 LOPES JR., Aury; ROSA, Alexandre Moraes da. Prisão obrigatória no Júri é mais uma vez inconstitucional. Revista Consultor Jurídico, 31 de janeiro de 2020. Disponível em: https://www.conjur.com.br/2020-jan-31/limite-penal -prisao-obrigatoria-juri-vez-inconstitucional. Acesso em 19.05.2020. 
Luis Régis Prado ${ }^{54}$, ao tempo em que foram louvadas por outros como Ricardo Andreucci55.

Todavia, sob nenhuma perspectiva, as modificações promovidas se coadunam com as conclusões deste artigo. Como já discutido anteriormente, a soberania dos veredictos não é uma garantia absoluta e deve sempre ser lida à luz da Constituição e dos demais direitos e garantias fundamentais do acusado, tais como o duplo grau de jurisdição e a presunção de inocência.

Para além de não haver justificativas para a fixação arbitrária do patamar de 15 anos de pena, a determinação da execução imediata em primeira instância como regra, independentemente dos fundamentos do recurso e da formação de coisa julgada sobre o mérito da condenação é modificação que padece de flagrante inconstitucionalidade, especialmente por violar o duplo grau de jurisdição.

Decerto que modificações poderiam ser promovidas pelo legislador para se redefinir o marco do trânsito em julgado no processo penal brasileiro, ou, ainda, poder-se-ia defender jurisprudencialmente a redefinição destes marcos a partir das perspectivas trazidas neste artigo. Todavia, sem que se fale de coisa julgada, mesmo parcial ou antecipada, a prisão apenas poderia se legitimar em uma perspectiva de cautelaridade.

Em muitas ocasiões, as evidências desta cautelaridade poderiam surgir ou serem reforçadas em plenário, implicando a prisão imediata após a condenação, mas, para estas situações, o sistema processual atual já basta.

\section{CONCLUSÃO}

A operacionalização do controle penal nas sociedades periféricas sempre enfrentou severas críticas acadêmicas, em razão das já conhecidas

54 PRADO, Luis Régis. Prisão pós-júri: mais uma panaceia?. Disponível em: http://genjuridico.com.br/2020/01/08/prisao-condenacao-pelo-tribunaljuri/. Acesso em 16.05.2020.

55 ANDREUCCI, Ricardo Antônio. Condenação Pelo Tribunal Do Júri E Execução Provisória Da Pena Na Nova Lei Anticrime. Disponível em: https:// emporiododireito.com.br/leitura/condenacao-pelo-tribunal-do-juri-e-execucao-provisoria-da-pena-na-nova-lei-anticrime. Acesso em 10.05.2020. 
discussões sobre seletividade, ampliação desmensurada dos espaços de risco, descontrole na opção de bens jurídicos tutelados, encarceramento em massa de condutas pouco lesivas, entre outras que demonstram uma clara tendência de expansionismo ilegítimo da lei penal e redução das garantias fundamentais processuais.

Em face de tais críticas, há igualmente uma tendência de rejeição imediata de toda e qualquer proposta político-criminal que parta de uma perspectiva legitimamente do poder punitivo, mesmo que elas se fundamentem na necessidade de conferir uma maior racionalização ao sistema de modo a potencializar a eficácia do Direito Penal como instrumento de proteção dos bens jurídicos.

Neste contexto pretendeu inserir-se o presente trabalho, intencionando fomentar um debate acadêmico acerca da necessidade de se repensar o momento de cumprimento de pena para os criminosos que atentem dolosamente contra a vida como forma de racionalizar o sistema e torná-lo minimamente eficaz, especialmente num país em que este tipo de crime atinge estatísticas comparáveis a zonas de guerra.

Buscou-se demonstrar que o aspecto constitucional pétreo do Tribunal do Júri, responsável pelo julgamento destes crimes, não derivou essencialmente de uma conclusão do Constituinte acerca de sua fundamentalidade, mas de uma declaração política de resistência ao autoritarismo e de um vislumbre da necessidade de se reinstituir a histórica tribuna para onde representantes da população são convocados a decidir o rumo de seus pares.

Independentemente das críticas que possa haver acerca do procedimento do júri, do processo de formação de seus convencimentos e da necessidade de reformulação de suas técnicas, é fato que a Constituição Federal soube reconhecer sua importância a ponto de lhe conferir o status de uma instituição soberana, e, portanto, com decisões insuscetíveis de reforma por qualquer instância do Poder Judiciário togado. É fato que o procedimento do júri é mais complexo e possui uma estrutura com mais espaços de defesa e garantia do que àquele reservado aos demais crimes. Estas opções político-constitucionais e legais não podem ser subestimadas ou reduzidas ao patamar de letra morta, tendo este trabalho investigado as diversas maneiras em que elas são consideradas na fixação de distintas regras procedimentais. 
Verificando-se a sentença condenatória como um ato subjetivamente complexo formado pela conjugação de vontade de dois órgãos distintos, pode-se perceber a possibilidade de formação de uma coisa julgada parcial da culpa em face da ausência de recursos, ou de possibilidade de recursos, quanto à parcela da decisão que coube aos jurados. Fixou-se, neste trabalho, a conclusão de que o recurso com fundamento exclusivo em dosimetria ou contra condenação proferida em julgamento refeito implica a possibilidade de início imediato do cumprimento da pena, desde a primeira instância, ante o trânsito em julgado da culpa.

Da mesma forma, em sendo as questões jurídicas atinentes à tipificação da conduta solucionadas na primeira fase do procedimento (submetidas, inclusive, a um duplo grau de jurisdição), e estando as Cortes Superiores destituídas da função constitucional de incursionar na conclusão fático-probatória da decisão soberana do júri para reavaliá-las, também se definiu haver a formação de uma coisa julgada da culpa na confirmação da condenação em segunda instância.

Não se podem rechaçar perspectivas político-criminais como a presente unicamente por ela reforçar os instrumentos coercitivos de um sistema penal contra o qual pesam tantas críticas. Modificações no sistema que, sendo constitucionalmente adequadas, visem incrementar a funcionalidade protetiva do Direito Penal como guardião de bens jurídicos, devem ser efetivamente tidas como relevantes e necessárias para o caminho de reformulação do sistema.

\section{REFERÊNCIAS}

ABRAMSON, Jeffrey. We, the jury: the jury system and the ideal of democracy. New York: Harvard University Press, 2000.

ALENCAR, Rosmar Rodrigues; TÁVORA, Nestor. Curso de Direito Processual Penal. 11 ${ }^{\text {a }}$ Ed. Salvador: Juspodivm, 2016.

ALEXY, Robert. Teoria da argumentação jurídica: a teoria do discurso racional como teoria da fundamentação jurídica. Trad: Zilda Hutchinson Schild Silva. $3^{\mathrm{a}}$ Ed. Rio de Janeiro: Forense, 2011.

ANDREUCCI, Ricardo Antônio. Condenação Pelo Tribunal Do Júri E Execução Provisória Da Pena Na Nova Lei Anticrime. Disponível em: https://emporiododireito. 
com.br/leitura/condenacao-pelo-tribunal-do-juri-e-execucao-provisoria-da-penana-nova-lei-anticrime. Acesso em 10.05.2020.

ARAS, Vladimir. Renúncia ao julgamento pelo júri no Processo Penal Brasileiro. Waiver of jury trial in Brazilian Criminal Procedure. In: CALABRICH, Bruno; FISCHER, Douglas; PELELLA, Eduardo (orgs.). Garantismo Penal Integral. $3^{\mathrm{a}}$ Ed. São Paulo: Atlas, 2015, p. 596-608.

BADARÓ, Gustavo Henrique. Processo Penal. $3^{\text {a }}$ Edição. São Paulo: Editora Revista dos Tribunais, 2015.

BOBBIO, Norberto. A Era dos Direitos. $8^{\mathrm{a}}$ Ed. Rio de Janeiro: Campus, 1992.

BRASIL. Lei no. 13.964, de 24 de dezembro de 2019. Disponível em: http://www. planalto.gov.br/ccivil_03/_Ato2019-2022/2019/Lei/L13964.htm.

BRASIL. Supremo Tribunal Federal. Acórdão no Habeas Corpus n. 126.292/SP. Tribunal Pleno. Relator Ministro Teori Zavascki. Julgado em 17.02.2016. DJe-100. Divulgado em 16.05.2016. Publicado em 17.05.2016.

CHAVES, Charley Teixeira. O povo e o Tribunal do Júri. Belo Horizonte: D’Plácido, 2015.

CHOUKR, Fauzi Hassan. A leitura do STF sobre o sistema recursal e o início da execução da pena: a pauperização do comparatismo à brasileira. Revista Brasileira de Direito Processual Penal, Porto Alegre, vol. 4, n. 3, p. 1119-1142, set/dez. 2018. https://doi.org/10.22197/rbdpp.v4i3.177

DAVID, Décio F.; BONATO, Gilson. Execução antecipada da pena: entre a garantia do estado de inocência, a coisa julgada e as teorias absolutas da pena. Revista Brasileira de Direito Processual Penal, Porto Alegre, vol. 4, n. 3, p. 1143-1174, set./ dez. 2018. https://doi.org/10.22197/rbdpp.v4i3.180

FRAGOSO, Heleno Cláudio. A Questão do Júri. Revista Forense. no ${ }^{193,1961,}$ p. 20-29.

LOPES JR., Aury; ROSA, Alexandre Moraes da. Prisão obrigatória no Júri é mais uma vez inconstitucional. Revista Consultor Jurídico, 31 de janeiro de 2020. Disponível em: https://www.conjur.com.br/2020-jan-31/limite-penal-prisao-obrigatoriajuri-vez-inconstitucional. Acesso em 19.05.2020.

LUÑO, Antonio E. Perez. Los Derechos Fundamentais. Madrid: Tecnos, 1995.

MARQUES, José Frederico. O júri no direito brasileiro. $2^{\text {a }}$ Ed. São Paulo: Saraiva, 1955.

MITIDIERO, Daniel. Cortes Superiores e Cortes Supremas: do controle à interpretação, da jurisprudência ao precedente. $3^{\mathrm{a}}$ Ed. São Paulo: RT, 2017. 
NICOLITT, André. Manual de Processo Penal. $6^{\text {a }}$ Ed. São Paulo: Editora Revista dos Tribunais, 2016.

NIEVA-FENOLL, Jordi. Coisa julgada. Trad.: Antônio do Passo Cabral. São Paulo: Editora Revista dos Tribunais, 2016.

NUCCI, Guilherme de Souza. Júri: Princípios Constitucionais. São Paulo: Ed. Juarez de Oliveira, 1999.

PACELLI, Eugênio; FISCHER, Douglas. Comentários ao Código de Processo Penal e sua Jurisprudência. 9ª Ed. São Paulo: Atlas, 2017.

PRADO, Luis Régis. Prisão pós-júri: mais uma panaceia?. Disponível em: http:// genjuridico.com.br/2020/01/08/prisao-condenacao-pelo-tribunal-juri/. Acesso em 16.05.2020.

RANGEL, Paulo. A coisa julgada no Processo Penal brasileiro como instrumento de garantia. São Paulo: Atlas, 2012.

RODRIGUES, Paulo Gustavo. A imprescindibilidade das instâncias de controle prévio da decisão do Tribunal do Júri: crítica à medida II do pacote anticrime. In: Boletim IBCCRIM. Ano 27. N. 317. Abril/2019.

RODRIGUES, Paulo Gustavo; KRELL, Andreas J. Uma análise crítica da argumentação constitucional utilizada pelo Supremo Tribunal Federal no julgamento do Habeas Corpus $n^{\circ}$ 126.292/SP. Revista do Instituto de Hermenêutica Jurídica. Ano 15, Vol. 22. Belo Horizonte: Fórum, 2012.

RODRIGUES, Paulo Gustavo Lima e Silva. Os efeitos da soberania dos veredictos na definição do momento inicial de cumprimento das penas impostas pelo Tribunal do Júri. 2018. Dissertação (Mestrado em Direito Público). Faculdade de Direito da Universidade Federal de Alagoas, Maceió, 2018. Disponível em: http://www. repositorio.ufal.br/handle/riufal/3250.

SARLET, Ingo Wolgang. A eficácia dos direitos fundamentais. Uma teoria geral dos direitos fundamentais na perspectiva constitucional. $11^{\mathrm{a}}$ Ed. Porto Alegre: Livraria do Advogado, 2012.

SILVA, José Afonso da. Curso de Direito Constitucional Positivo. 26 ${ }^{\text {a }}$ Ed. São Paulo: Malheiros, 2006.

STRECK, Lênio Luiz. Tribunal do Júri: símbolos e rituais. $3^{\mathrm{a}}$ Ed. Porto Alegre: Livraria do Advogado, 1998.

TASSE, Adel El. Tribunal do Júri. Curitiba: Juruá, 2006. 
THAMAN, Stephen C. Spain returns to Trial by Jury. In: Hastings International \& Comparative Law Review. Vol. 21, n. 241, 1998. Disponível em: <https://ssrn. com/abstract=2571420 > . Acesso em 12.02.2018.

TOQUEVILLE, Alexis de. A Democracia na América: leis e costumes. $2^{\mathrm{a}}$ Ed. São Paulo: Martins Fontes, 2005.

VASCONCELOS, Vinícius Gomes de; GALICIA, Caíque Ribeiro. Tribunal do Júri na Justiça Criminal Brasileira: Críticas e Propostas de Reforma para a Restituição de sua Função de Garantia no Processo Penal Democrático. Revista Eletrônica de Direito Processual - REDP. Volume XIII, n. 13 (2014). Disponível em: <https:// www.e-publicacoes.uerj.br/index.php/redp/article/view/11940>.

\section{Informações adicionais e declarações dos autores (integridade científica)}

Declaração de conflito de interesses (conflict of interest declaration): o autor confirma que não há conflitos de interesse na realização das pesquisas expostas e na redação deste artigo.

Declaração de autoria e especificação das contribuições (declaration of authorship): todas e somente as pessoas que atendem os requisitos de autoria deste artigo estão listadas como autores; todos os coautores se responsabilizam integralmente por este trabalho em sua totalidade.

Declaração de ineditismo e originalidade (declaration of originality): o autor assegura que o texto aqui publicado não foi divulgado anteriormente em outro meio e que futura republicação somente se realizará com a indicação expressa da referência desta publicação original; também atesta(m) que não há plágio de terceiros ou autoplágio. 


\section{Dados do processo editorial}

(http://www.ibraspp.com.br/revista/index.php/RBDPP/about/editorialPolicies)

- Recebido em: 03/12/2019

- Controle preliminar e verificação de plágio: 10/12/2019

- Avaliação 1: 19/12/2019

- Avaliação 2: 01/01/2020

- Avaliação 3: 17/01/2020

- Decisão editorial preliminar: 15/03/2020

- Retorno rodada de correções: 19/05/2020

- Decisão editorial final: $21 / 05 / 2020$
Equipe editorial envolvida

- Editor-chefe: 1 (VGV)

- Editor-assistente: 1 (TAJC)

- Revisores: 3

\section{COMO CITAR ESTE ARTIGO:}

RODRIGUES, Paulo Gustavo. Redefinindo o trânsito em julgado a partir da soberania dos veredictos: a coisa julgada parcial no tribunal do júri. Revista Brasileira de Direito Processual Penal, Porto Alegre, vol. 6, n. 2, p. 873-910, mai./ago. 2020. https://doi.org/10.22197/rbdpp.v6i2.301

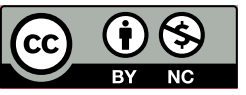

Esta obra está licenciada com uma Licença Creative Commons Atribuição-NãoComercial 4.0 Internacional. 